\title{
Local and Transnational Flow of Icons, Images and Symbols
}

\author{
Stephen Fọlárànmí Nanashaitu Umoru-ọ̀kẹ́ \\ Department of Fine \& Applied Arts, \\ Ọbáfẹ́mi Awólộwọ̀ University Ilé-Ifẹe Nigeria
}

\begin{abstract}
Known studies on the arts and literature of Africa have highlighted the roles that African Arts played in the documentation of the people's history, culture and general existence. The revelations and history of many communities have actually been made possible by the arts they produced or left behind in abandoned or existing communities. These arts was a major form of writing before the contact with other parts of the world, even after such contact the culture of using art as a language continued though on a reduced scale or intensity than previously used or utilized by the people. Examples of these imageries and symbols are found in the àrokò, a powerful form of information dissemination among the Yorùbá people in Nigeria. They are also found on several of the sculptural pieces, on traditional woven clothes, calabashes, ritual and utilitarian pots as well as on the several traditional mural paintings among the Igbo, Yorùbá and Ibibio in Nigeria. Many of the artists used these icons and symbols to discuss social, religious and historical issues even beyond their local environment. This paper examined the images and symbols found on selected traditional art forms and how selected Nigerian artists within and outside Africa have utilized these images as a potent force and language in the creation of contemporary works of arts. The paper employs iconographic and contextual methods to interrogate and analyse these images as epitomized in their works and also the changes that these images have experienced in their new place of exposure and usages.
\end{abstract}

DOI: $10.7176 / \mathrm{ADS} / 72-01$

Publication date: April $30^{\text {th }} 2019$

\subsection{Introduction}

Traditional African art forms are replete with numerous icons, symbols and imagery that is unique. They are often embedded with coded information and meanings that are sometimes difficult to decipher, especially when they have been taken out of the context from where they were meant to be. Even the functional or utilitarian objects like spoons, stools and other items ornately decorated with motifs and icons sometimes to add more value to them. Icons according to Parrinder, (1967:13) are symbols used to illustrate proverbs, tales, folklore, myths, and stories, expressing both the culture and wisdom of the people. He also goes on to state that African art was the only writing known in the whole of tropical Africa, it was used to interpret life in every aspect, showing, man in his stages of existence, birth, life and death.

Parrinder's view is right in many instances in Africa, however, there is evidence that some African communities had some form of writing that was developed, but only restricted to members of the particular society. The Ejagham people in Southeastern Nigeria and Western Cameroon are examples of such. Detailed studies on these have been carried out by Thompson (1984). From the ancient times to the present many artists have always used these icons, symbols and images as a form of identity, as well as to express Parrinder's view above. Since it was usually a communal art form, the identity of the people were more pronounced and projected than that of the individual artists who produced them. Their religious beliefs and philosophy were all embedded as icons visualizing the collective culture of the people.

In the post-independence Nigeria, artists especially from the Zaria School (Ahmadu Bello University, Zaria) had jettisoned the prevalent western styled mode of representation as they were being trained in the University by borrowing from the traditional African arts to produce works that were modern, but in content relating to the society in which they were created. These experiments were not only peculiar to Nigeria, but also other parts of Africa where the culture of self-actualization started taking root (Senegal, Ghana, Mozambique, Uganda and Kenya). The emerging modern artists from these cultures drew largely from their traditional art forms in creating new forms.

Much has been written about the artistic development of the Africans in the different parts of the world where the slave trade took them. Many of these images and icons travelled at the different levels and germinated in the new lands where the people never forgot about their culture and its artistic heritage. Discourses on these are found in studies about African art in Diaspora. Thompson (1984) and Okediji (2003 and 2007), both looked at the various aspects of the African art and artists as they cross the Atlantic into the Americas and the influence of their art on the new found societies.

One of such examples is the image of a man with bow and arrow (Fig. 1) painted on the entrance wall of the Oyo palace, identified to either be a warrior or hunter (Folaranmi, 2012:98). The hunter probably represents those who killed wild animals for the Aláàfin (the title of Òyó king). The bow and arrow was a very important 
aspect of the Yorùbá warfare before the contact with the Europeans who introduced guns about the sixteenth century. This icon is particularly used widely in other parts of the world where the Yorùbá religion and culture have been transported. In Benin Republic, Bahia and Salvador in Brazil, Cuba and Trinidad and Tobago, emblems such as the arrow and bow are usually combined with other tools and implements as insignia of Ògún, the Yorùbá god of iron and Oshoosi, Ògún's mythic brother and companion. Thus across the Atlantic iron implements are seen as children of Ògún (Thompson, 1984:58-61).

Thompson, also gave examples of metal bows (orún) and arrows (ofà) also for Oshoosi, which is said to be fashioned in the Nigerian ideographic pattern, and has taken root among the Blacks of Bahia. Sometimes called damata oshoosi. Jose Adario dos Santos, a Salvadorian artist (blacksmith) at his forge created the pieces (Fig. 2 and 3) following firm Yorùbá canons of expression while at the same time designating modern tools of iron as extension of Ògún's realm. There exist numerous artistic traditions among the Yorùbá, Igbo and other ethnic groups in the eastern part of the present day Nigeria on which symbols and iconic images are found. Some of these are found on calabash carvings, murals, and wood carvings in panels, pillar posts, stools, and mortars, as well as pottery used domestically or for religious purposes. Today many artists of African origin still use these icons and images in their various artistic creations.

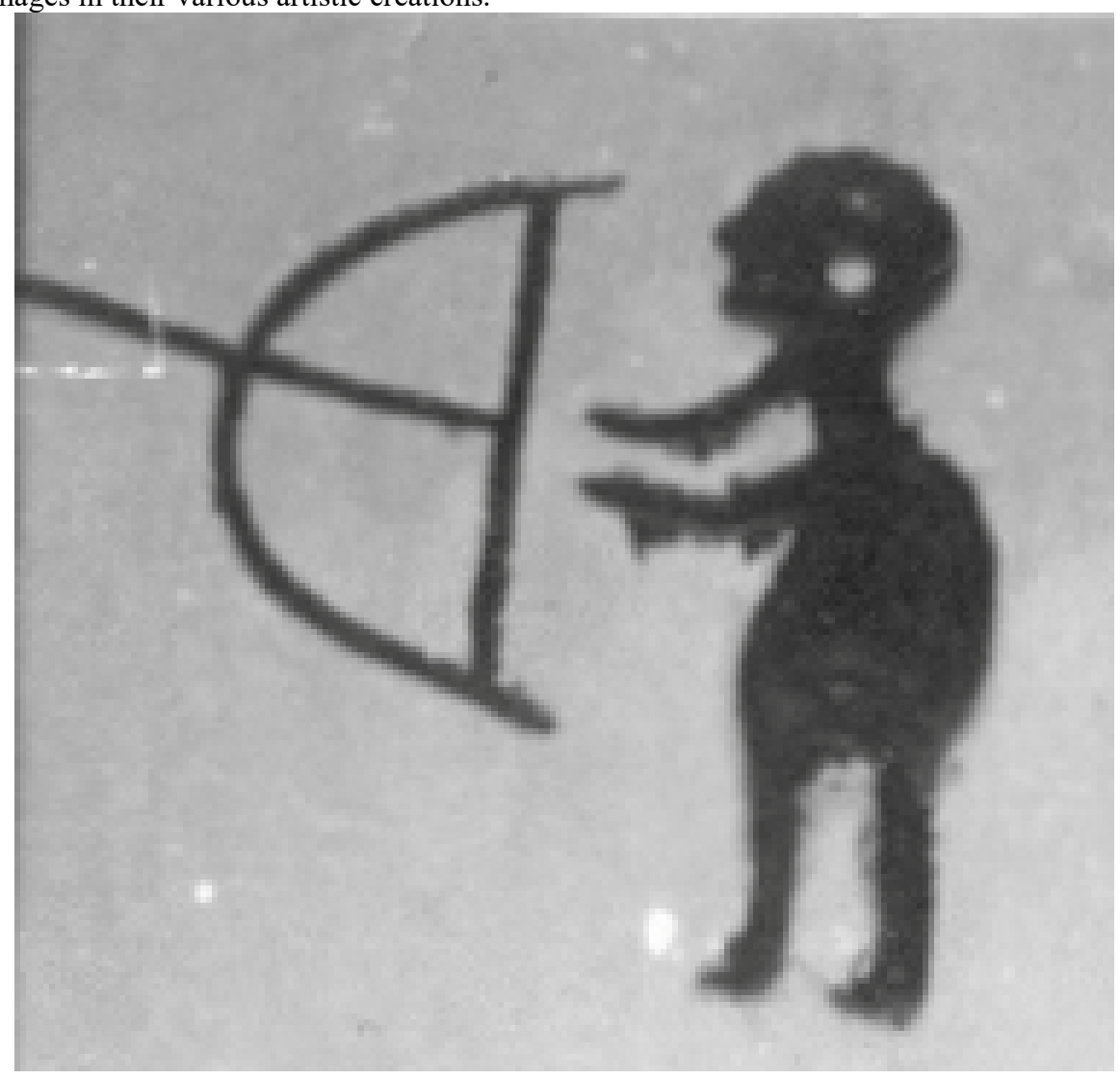

Figure 1. Image of man with bow and arrow on the Oyo mural by Salami Alábèbè. Photograph by Stephen Fọlárànmí, 2010 


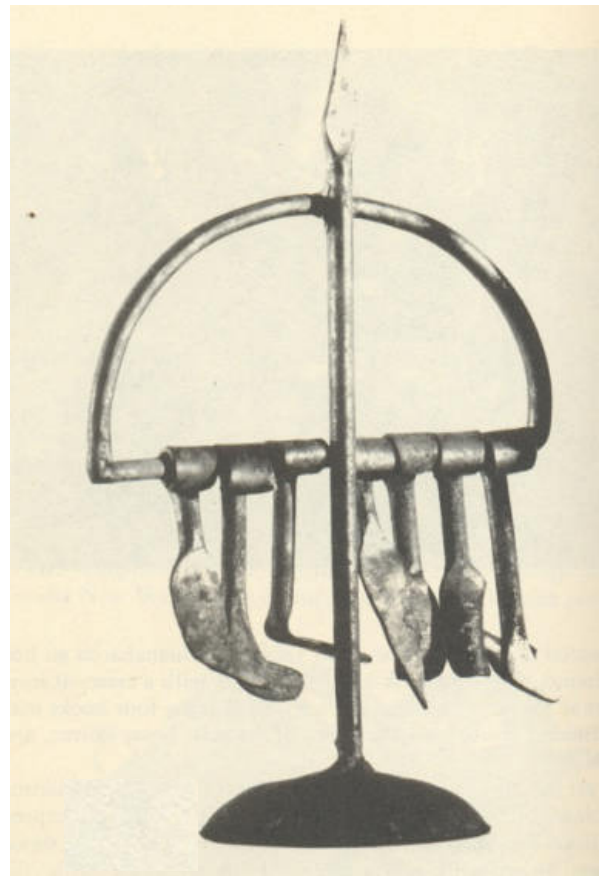

Figure 2. Ferramentas de Ògún by Jose Adario dos Santos. Courtesy of Robert Farris Thompson, 1984.

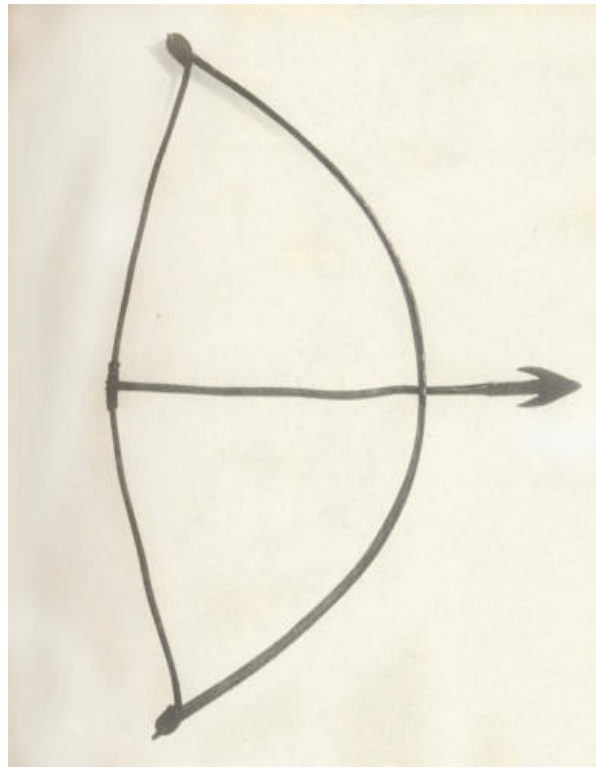

Figure 3. Metal bows (orun) and arrows (ofà) also for Oshoosi, which is said to be fashioned in the Nigerian ideographic pattern. Courtesy of Robert Farris Thompson, 1984. 


\subsection{Search for the Soul of African Art by Contemporary Nigerian Artists}

Perhaps it is relevant to mention that in the search for the soul of the African art creativity some Contemporary Nigerian artists have specifically gone back to their origin to root out forgotten imageries, symbols and icons that had been hitherto confined to the walls of shrines, or on items used for religious purposes. Uche Okeke, a foremost Nigerian artist was who was instrumental the rebirth of $u i l^{1}$. Okeke, with other artists in the eastern part of Nigeria were concerned with creating a national culture rooted in Igbo culture. Almost like a response to $u l i$, a set of artists and scholars from Ile-Ife, a university town in the southwestern part of Nigeria looked in the same direction as Okeke and gave birth to what is now known as oná. ${ }^{2}$

Aside from these movements, others have been content only to identify with and use such motifs, symbols and icons in their works without bordering about belonging to a group. Others enjoyed the development of art workshops such as the Mbari Mbayo in Òșogbo and Orí Olókun in Ilé-Ifẹ̀ where the focus and instruction according to Mount (1989:148) was on creating and stimulating students to evoke the depth of their consciousness and highly individual images. These were usually drawn from the experience of their tradition and not on any preconceived Western styled art.

These artists are classified into three major categories. The first artists are resident in Nigeria. The second are those who have relocated to different parts of the world to continue their art practice and where these images and symbols now engage in various discussions and changes (diaspora). The third are those who have engaged in what Harris and Okediji, (1999:33-51) termed as 'remembering'. These artists are those with roots from Africa, roots that transcends the slave trade. These artists work with media and forms that they may not have physically experienced, but like spiritual beings, relate back to their roots and draw inspiration for their artistic creations. Some of these artists are also referred to as returnee artists; the African American artists who have journeyed to Africa and who use African images or refer to Africa in their works. This paper therefore concerns itself with the first and second classifications, it examines the transnational flow of the symbols, images and icons in their works since more studies seem to have been done on the influences of these images and symbols in the works of the third category of artists than on artists who still work in Nigeria.

\subsection{Meaning and Iconography in African Arts}

The search for meaning in art is a subject which art historians over the years have constantly engaged in, as new works are produced daily, so is the plethora of challenges faced by art critics and historians, leaving at their doorsteps images, compositions and riddles to decipher (D'Alleva, 2012). Today, the search continues into all aspects including iconography and iconology. Panofsky, (1970:26-41) describes iconography as that branch of the history of art which concerns itself with the subject matter of meaning of works of art, as opposed to their form. Icons make all sorts of statements; they can be narrative; signs of identification, comments, or may not even make any comment whatsoever. To this end, artists sometimes create icons and imageries to communicate special messages to the viewers. Sometimes the full meaning of icons can be quite complex because of the situation in which they appear, especially in the present context. Many artists today use some of these icons or symbols not particularly because of the understanding of their meanings, but because it identifies their works as being produced from Africa or by 'African' artists. Considering the above, it will be relevant to examine the juxtaposition of several icons in a larger ensemble as evident in the works of the selected artists.

\subsection{Local Movement of Images and Symbols}

The artists whose works are examined fall into categories of artists who have been involved and use images and symbols significantly in their artistic production over many years. They have been consistent, and are knowledgeable about these icons, symbols and images, and are able to apply them to discuss contemporary issues. Many of these artists (Kunle Filani, Bolaji Campbell, Adémọ́lá Ògúnàjọ, Adéyínká Okùnadé and Mufu Onifádé) have benefited immensely from the result of the studies of particularly traditional Yorùbá art forms; hence the successful introduction and fusion of such traits into their works.

Artists such as Òkédijí, Campbell and Ekpuk (diaspora artists) resonates here because their journey as artists started at 'home', taking directly from the local content and extending the frontiers of their art beyond the realms never imagined by the ancient artists. In addition to this, they have been instrumental to the interests in the Yorùbá traditional art forms by generation of young artists such as Adémọ́lá Ògúnàjọ.

\footnotetext{
${ }^{1}$ Uli is a form of design traditional to the Igbo people of Southeastern Nigeria. These brightly coloured line drawings are painted unto walls of houses, palaces and shrines, or on women bodies during important ceremonies. The tradition had more or less died until Uche Okeke and a group of other artists started exhibiting interest in it and later forming the core of the ideas behind the Nsukka School of Art. (See Kawaguchi, 2011)

${ }^{2}$ Onà is a Yoruba word meaning design, decoration aesthetic and Art, the word stands for beautification of things such as wall, wood, metal, cloth, pottery calabashes and even human bodies. It is also a name by which a group of artist and graduates for the University of Ife were called. Onaism as a movement therefore stands for, "any formal or thematic concept of art rooted in the creative projection of Yoruba designs, forms, and Philosophies in this contemporary era.
} 


\subsection{Adaptation of Yorùbá Images in Adémọ́lá Ògúnàjọ’s Paintings}

The deep Yorùbá culture and tradition is highly exhibited in the paintings of Adémọ́lá Ògúnàjọ ${ }^{1}$. A 1995 Fine Art graduate of Ọbáfẹ́mi Awólọ́wọ̀ University Ile-Ife, Ògúnàjọ took an interest in carving where Lamidi Fakeye, Moyo Òkédijí and Bolaji Campbell ${ }^{2}$ were the Lecturer. Ògúnàjọ creatively utilized his interest and knowledge acquired in the carving classes to develop a new form of expression in his paintings. The themes and subject matters in painting assignments given by Òkédijí and Campbell also served as a catalytic effect and influence in the adaptation and development of this new style. Such themes for pictorial representation were very rich in Yorùbá folklore, stories, myths and social activities.

Ògúnàjọ's works illustrates in two-dimensional forms, what Fakeye represents in wood. His images however gave more life, and color which is the greatest tool of the painter. A vivid example of such adaptation is exemplified in 'Exodus', 2001 (fig. 4). Exodus reminds one of a probable scene surrounding a traditional Yorùbá house or palace several hundreds of years ago, especially before the desecration of such wonderful architectural beauty. These were usually decked with pillar posts, carved stools, mortars many of which were looted and carted away to museums and galleries all over the world. Exodus according to Ogunajo, (2001) expounds the exodus of our cultural germs (essential catalysts) in the face of readymade, well packages items of luxury that Nigerians have come to cherish to the detriment of locally produced goods. In those days, the pillar posts supporting the house had life in them, life that speaks to the people. These pillar posts speak victories and conquests; the detailed craftsmanship of the sculptors constantly reminds one of his/her lineage.

In this painting all the figural representations, from the house posts to the people wading in flood are adaptations from the Yorùbá traditional sculpture that Fakeye represents. It is a constant feature in Ògúnàjọ's works, aligning to the proportion of significance, which is an important pivot on which most Yorùbá sculpture rests. In Yorùbá philosophy, some parts of the body are considered more important than the others. The head, which is the seat of power, intelligence and destiny, is the most important and it takes one third of the whole body (Idowu 1962; Ajiboye, Fọlárànmí, and Umoru-Oke 2018). The reproductive organs especially the breasts and the phallus are also exaggerated, because it is through them that humans perpetuates their existence on earth; an instrument of continuity and identification of sex.

Ògúnàjọ's lack of satisfaction with academic tradition and ideas led him into creative experimentation and synthesis of form, thereby arriving at a new vision. Through this vision, he has responded to changes in life which according to Folarin, (2001) compels the creative artist to find new ways to digest and talk about new and past experiences. Though his work now engages in thoughts about the present, his rendering is from the tradition, which gave birth to him (Folárànmí 2002).

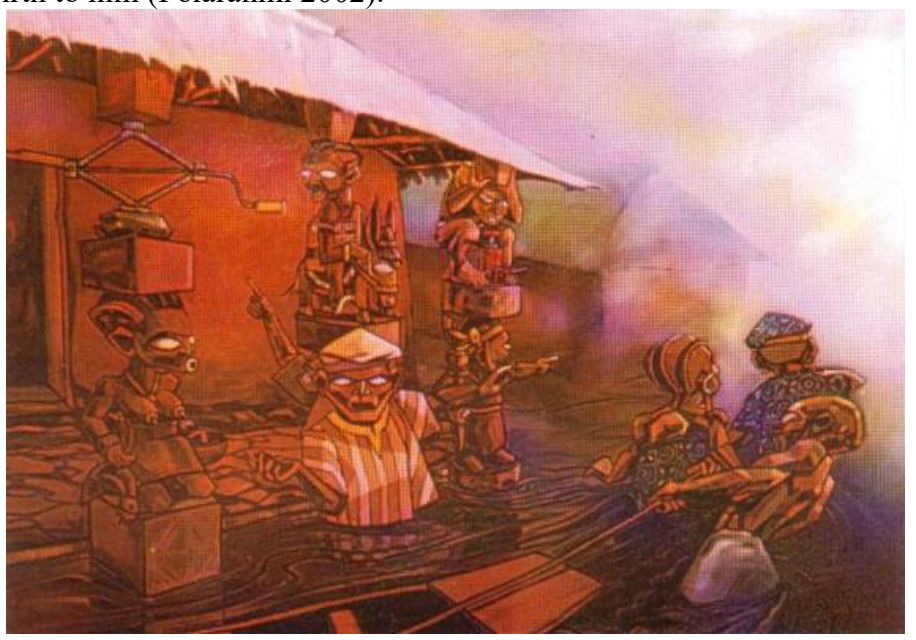

Figure 4. Ogunajo Ademola, Exodus 2000, acrylic on canvas. $8 \times 4$ feet, Photograph by Ademola Ogunajo, 2000.

\subsection{Araism and the works of Múfú Onifádé}

Múfú Onifádé's love for the effect of cracks created by wax on batik gave him an insight to a style, which he has christened 'araism'. His idea was a conscious effort to be different; nevertheless, it is also an adaptation. His experiment passed through some trial stages especially in the use of materials before he settled for the use of tempera on canvas. His expressions are essentially expressionistic revolving around organic and dramatic rein of

\footnotetext{
${ }^{1}$ See (Ogunajo 2001)

${ }^{2}$ Late Lamidi Fakeye, a fifth generation Yorùbá wood carver from the northeastern Yorùbá city of Ìlá Ọ̀ràngún was a lecturer in the Department of Fine Arts along with Moyo Òkédijí and Bolaji Campbell.
} 
forms and colours. There he delves into the use of ocres, the colour of mother earth, an influence from the study of Yorùbá shrine paintings that had been brought to lime light by the pioneers and founders of 'oná' group and 'Best of Ife'.

It is glaring that from the throes of oná, Múfú adapted the oná within him for himself, rendering 'araism', a derivative of oná. His themes rendered mostly with anatomical reality are Yorùbá in content. Two paintings, İróké, 2008, (fig 5) and Asộrọ dayọ, 2006 (fig 6) express succinctly the use of images and symbols in the works of Onifádé. Aside from borrowing or adapting the images and symbols in his works, most of Mufu's paintings are titled in Yorùbá language, which he claimed gives identity and relevance to his painting.

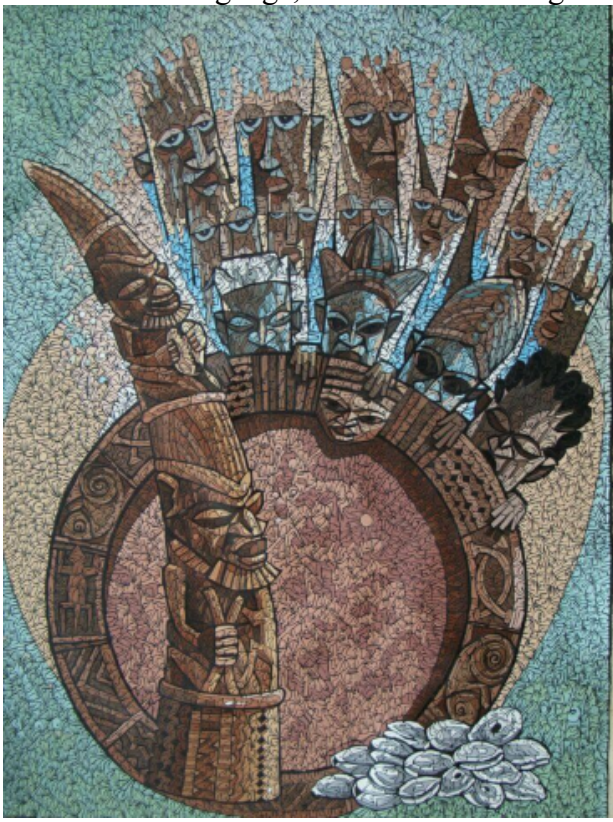

Figure 5. Múfú Onifádé. Iroke, 2008, acrylic on canvas, $90 \times 122 \mathrm{~cm}$. Photograph by Mufu Onifade, 2008

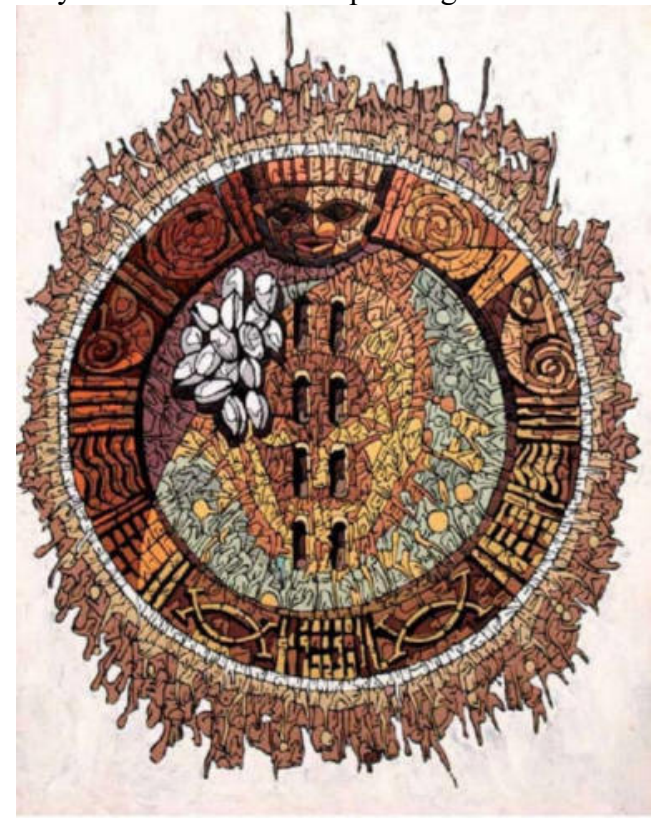

Figure 6. Múfú Onifádé. Asòròdayò, acrylic on canvas, $55 \times 69 \mathrm{~cm}$.

Photograph by Mufu Onifade, 2008

İóke for instance elevates the importance of that ivory imagery in Ifá divination, a function that cannot be under estimated by the babaláwo - Ifá priest. During divination Ợúnmilà is invoked by the iróke by the tapping the divination tray, opọ́n Ifá. This is in addition to the babaláwo reciting the oriki or praise songs of Ọrúnmilà (Abiodun 1989)

Behind the iróke is the opọ́n Ifá, a beautifully crafted piece circular divination tray central to the Ifá oracle inlaid with an array of symbolic elements like the lizard or gecko, chameleon and the ever-constant face of Ėșù the trickster god. Somewhere on the tray, Múfú has also borrowed another icon foreign to the opón Ifá or the Yorùbá. It is an nsibidi symbol which means husband and wife, love, relationship and unity, a common feature in the paintings and drawings of Victor Ekpuk. Its inclusion here also show how many of these images cross boundaries from one place to the other, used sometimes to connote new meanings of functions different from where it may have originated from, or with the same meaning in mind. Hanging tenaciously to the edges of the opọ́n ifá are faces of four Ifá devotees who are patiently waiting for Ọrúnmìlà to speak through the babaláwo. Their faces are expectant, with bulging eyes and features still reminiscent of Yorùbá traditional sculpture; while the other faces devoid of the same Yorùbá sculptural outlook are those who see Ifá devotees as heathens. The importance of Ifá in Yorùbá cosmology is further stressed in Asọrọ dayọ (fig. 6) where the central theme and only imagery in the painting is the opọn Ifá. The depressed and central face of the board is marked with odù òyẹkú méjì, an indication that there is already an act of divination carried out by the babaláwo.

The motifs and symbols intricately molded as if carved on the borders of the trays is similar to that of the previous painting İróke, but with the absence of the gecko or lizard motif and a duplication of the nsibidi symbol. It is said that the varieties of the images which are arranged around the border "articulate a cosmos of competing, autonomous forces" and are meant to "praise the momentous work of diviners as they seek to disclose the forces in the situation"(Drewal et al. 1991). Furthermore, the richness of the design on the border of the opón depends largely upon the means of the person who commissions the piece. Hence people, animals, birds, cultural items, combine to express the themes of leadership, warfare, protection, sacrifice and others (Hackett 1999). The introduction of the nsibidi symbol however alien it might be today somehow subscribe the assertion above, it shows the changes that this religious item have witnessed in the hands of the artist in the twenty-first century. An 
artist who now holds more than the Yorùbá world view by inculcating virtues and ideas that is positive from other cultures. While Ògúnàjọ and Onifádé utilize images drawn from the more than one African ancestry, Filani draws significantly from the icons, motifs and symbols embedded in the traditional Yorùbá art.

\subsection{Motifs and Icon as Metaphors in the Paintings of Kúnlé Filani}

Kúnlé Filani ${ }^{1}$ an illustrious member of Onà, who seems to have deliberately gone philosophical with his paintings in which more attention is given to motifs, patterns and symbols constituting his subject matter thus taking onà ideas beyond embellishments (Adémúlèyá 2007). An example of such works is Vestige of the Past (fig.7). The mixed media painting on canvas derives much specifically from the mural by Salami Alábèbè on the front wall porch of the Oyo palace. Here, Filani incorporates the icons such as the ostrich, the sword, the hare, the concentric snake and the reptile into this painting, to discuss and produce in modern form the history of yesterday that Alábèbè chronicled for the Aláàfin of Oyo. Filani has constantly used the traditional Yorùbá Fabric, especially the old ones to talk about age, value and the social fabric of the Yorùbá people, no wonder the entire composition in the painting is mounted on such painterly background. One will best understand and appreciate this more when you visit the expansive wall of the palace at Oyo (Folaranmi 2012).

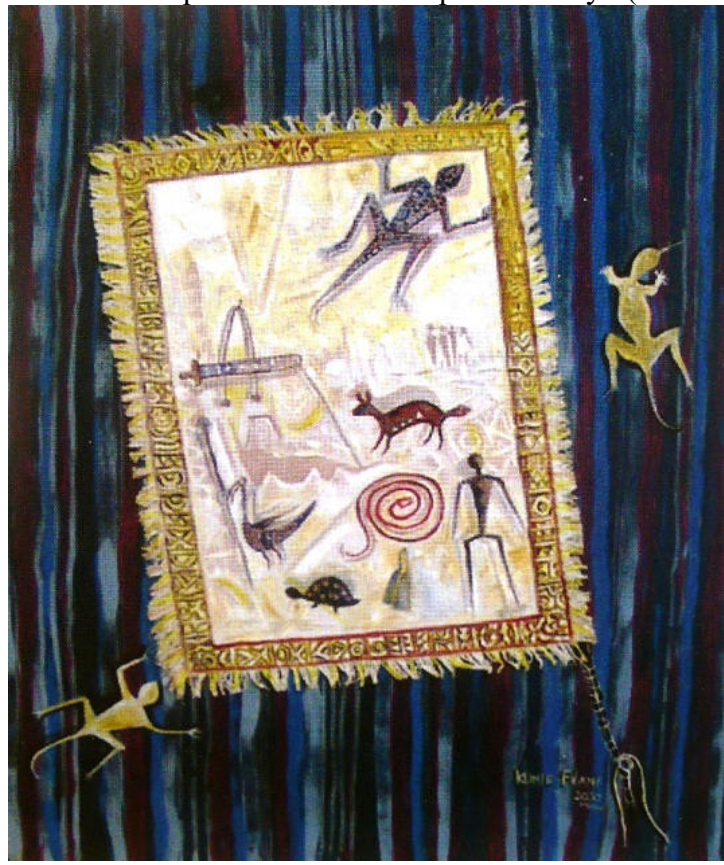

Figure 7. Kunle Filani, Vestiges of the Past, mixed media, 2002. Photograph by Babásẹ̀ìndé Adémúlẹyá

\subsection{Bolaji Campbell: An Extension of tradition in the New World}

Bólájí Campbell, an Associate professor at the Rhode Island School of Art and Design, is one of the founding members of the Onà Group of artists. He taught at Obafemi Awólộọ̀ University, Ile-Ife between 1989 and 1996 before relocating to USA. In 'African Renaissance', Okediji, (2002) examines the works of Yorùbá artists who have migrated from Yorùbá land to the West, he analyses the works of these artists in terms of their continuities and breaks from the Yorùbá tradition, by mentioning Moyò Ògúndípè ${ }^{2}$ and Bólájí Campbell as two of such artists who like others freely draw from Yorùbá sculptures, textiles, and mural painting traditions.

Campbell considers adaptation, influences and the transmission of the Yorùbá shrine painting tradition beyond the confines of the sacred walls and altars of orișà onto the center stage of academic traditions in his works. In a number of his essays, Campbell goes more religious in the exposition of artists who have derived inspiration from the Yorùbá shrine paintings when he describes some of the artists as inheritors of the tradition (ají jogún àsà) Campbell, (2008). An example of such work is a Reconstruction of a Yòrubá Shrine (fig. 8). This was done eight years after Campbell relocated to the United States.

\footnotetext{
${ }^{1}$ Kunle Filani is one of the founding members of the Ònà Group of Artists as well as the brain behind the Best of Ife Exhibitions. He is a critique, Artist of note and Administrator. He was the immediate past Provost of the Federal college of Education, Òsílè, Abeokuta, Nigeria. ${ }^{2}$ Moyò Ògúndípè (1948-2017) is a graduate of University of Ife, now Ọbáfẹmi Awólộọ̣ University, Ile-Ife.
} 


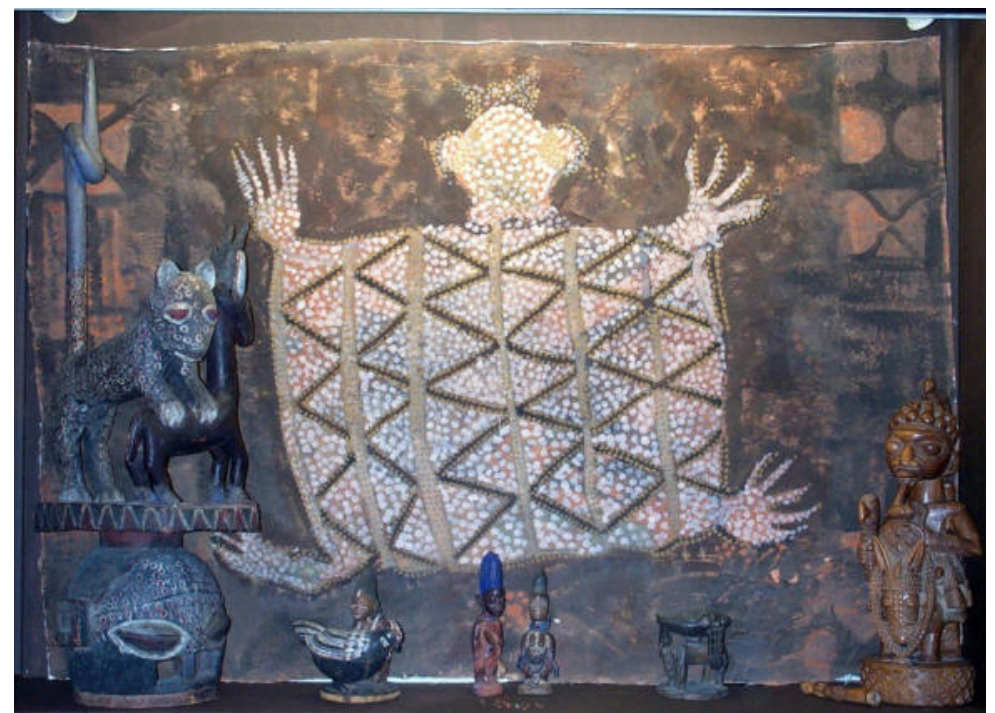

Figure. 8. Bólájí Campbell, Reconstruction of a Yoruba Shrine (Installation) mixed-media, 2004. Photograph by Bólájí Campbell, 2004.

Like Òkédijí, Campbell remains one of the artists who still use organic pigment derived from the earth and other vegetable materials. The imagery is further strengthened by the theme he often uses. In the painting that forms part of the reconstruction of a Yòrubá shrine, Campbell goes back to his studies of İrèlè shrine painting in İkìrun a Yorùbá town. From the arrays of imagery on the shrine painting, Campbell selected the tortoise as the central image for the painting. The tortoise is segmented into six vertical partitions, with zig-zag lines carefully drawn into each of the segments. Small white dots fill the entire body, as well as the limbs and head of the tortoise. The dots are a constant creative device found in most Yorùbá paintings created for the orì̀sà, especially paintings for Obàtálá ${ }^{1}$ who is also known or called a variety of names in different locations. Campbell (2008:130) expresses that it is specifically employed to intensify the visual and aesthetic qualities of the mural and as a visible means of communication with the divine.

In the foreground are carved epa mask (extreme left), olumèye bowl, ibejì figures, a small caryatid stool and an equestrian figure. These are added to complete the typical scenery of a Yorùbá shrine with all items that are used in worship or items that create a scared aura within the shrine. It is imperative to note that both the religious and secular Yorùbá murals are relevant in contemporary African Arts today and this cannot be overlooked. These are evident in the few works of the artists under study. The few studies on this subject however fail to justify the substantial evidence available in the works of many other artists especially among Yorùbá artists. In the diaspora, Campbell and a few others have also carried along these traditions, although not in the sense of propagating the religious aspects and practice of the òrisà, but as a means of repositioning the art of the shrine and its relevance in the twentieth century.

\subsection{Adeyinka Okunade. Aje}

Sân làá rìn,

ajé nii múni pẹkoro

We should walk or act directly

However Aje (deity of wealth) influences us otherwise

The themes and subject from the ceramic sculptures of Adéyínká Okùnadé are usually derived from Yorùbá lores, folktales and aphorisms. Okùnadé builds up his works from the vantage point of his knowledge about his language and culture using terracotta as a medium. Works such as $A$ o merin joba, Opon Ifá and Aje are examples of his creative output for more than three decades of artistic practice. Aje ${ }^{2}$ (figure 9), a terracotta piece draws from the Yorùbá view of wealth which is often symbolized by the cowrie. Aje is a pot belly shaped structure. The pot takes the form of a potbellied man signifying the wealth he displays. A large cowrie ${ }^{3}$ depicts

${ }^{1}$ Obàtálá, sent by Olodumare to create human beings and all other natural forms is one of the most important deities in Yorùbá land. He is known with different names in different parts of Yorùbá land; as Òrìsà pópó at Èjìgbò; Òrìsà-nla at Ibadan; Ado-Èkìtì and Ile-Ife; Ọbàtálá at Ọbà; İkirè, İjàiyè, Iwofin and Egbá district and as Irele in Ìkìrun.

2 Aje is a goddess of wealth and economic prosperity among the Yoruba of south west Nigeria. This òrìsà aid the accumulation of wealth and prevent dwindling of one's economic growth. Ajé could also refer to money.

${ }^{3}$ Cowrie was one of the most successful and universal form of currency all over the world. In Africa, it takes on a deeper meaning and function in both secular and ritualistic aspects of the people's life. For instance among the Yoruba, the representation of hundreds of 
the head (ori), metaphorically showing that aje is very important in all that man intends to achieve. This is further confirmed in another Yorùbá proverb which says 'owó ní tí òhun ò bá sí nílé, ki e ma dá 'mọ́ràn lehìn òhun - 'money says in my absence do not plan for anything. His head has however been replaced with a cowrie. $\mathrm{He}$ is adorned with a necklace and beaded hand bracelets on both hands. He stands on a pedestal with perforated holes and serrated triangular lines.

This potbellied figure of a man signifies that he is wealthy, well fed and does not care about what happens to any other. This is expressed in bámú bámú ni mo yó, à wa ò mọ pé ebi n pan ẹi kakan, a Yorùbá proverb meaning 'I am satisfied, filled to the brim; I am not bothered about those who are hungry. This proverb alludes to the nonchalant attitude of many rich people and some political leaders. This is evident in the political system in many African States where the presidents and their cabinet members live in affluence while citizens of the country wallow in abject poverty. This piece therefore is a socio cultural commentary, it interrogates the subject of the 'haves and the haves not' in our society. A reflection of the gap between the poor and the rich which continues to increase without an end in sight.
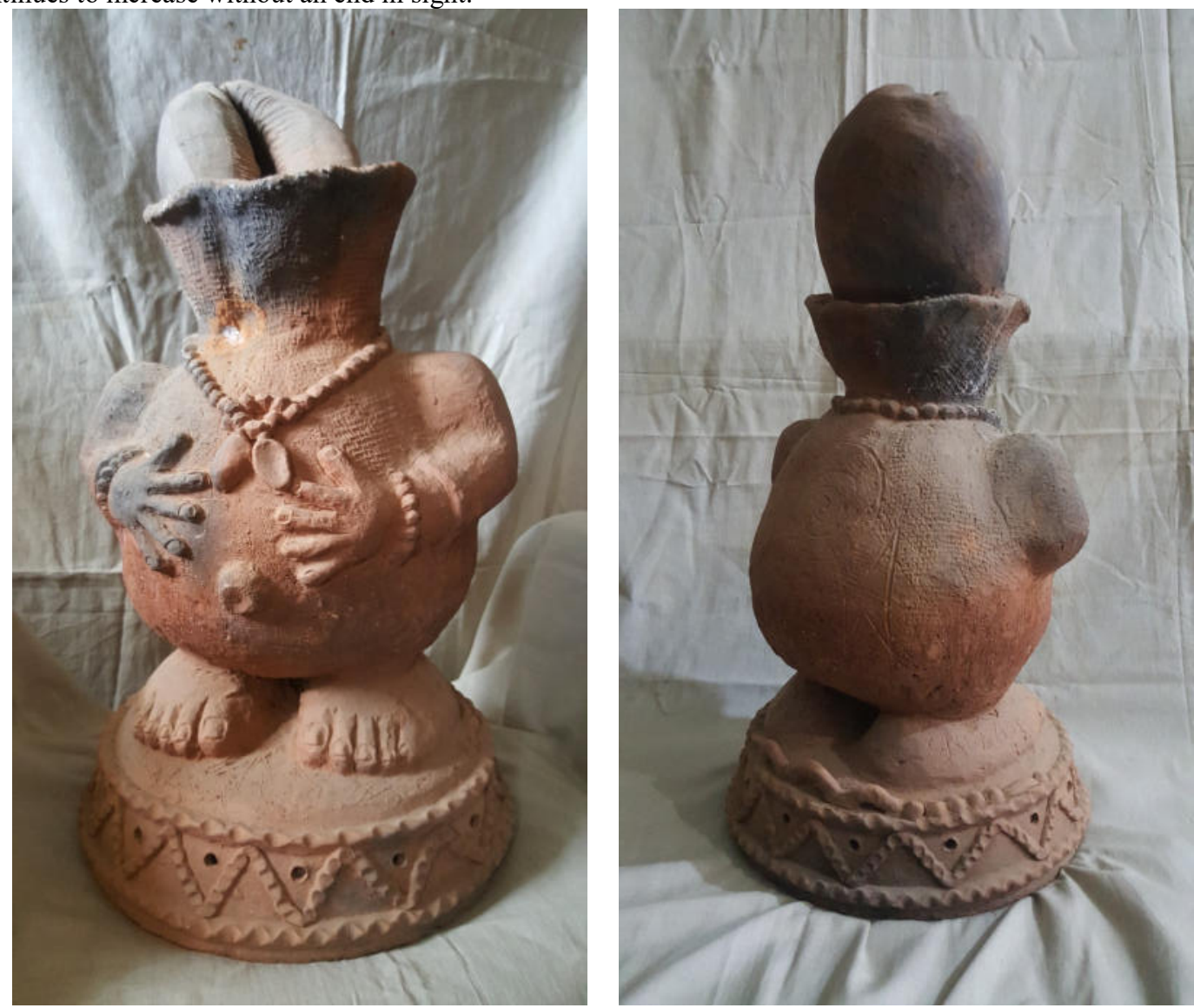

Figure 9. Adeyinka Okunade, Aje, 1998. Terra cotta 53 x 29 x $25 \mathrm{~cm}$. Photograph by Nanashaitu Umoru-Oke, 2018.

Apart from Yorùbá artists, there are other Nigerian artists (Victor Ekpuk, John Amifor and Don Akatapo) who by virtue of studying at the Ife Art School have imbibed the platform provided by Yorùbá arts to further develop their own artistic genius, looking inward to derive from their own traditions viable sources of inspiration, motifs, forms and images. Like Campbell, Victor Ekpuk is one of the generations of talented Nigerian artists who have explored this artistic tradition. 


\subsection{Nsibidi and the Script drawings and Paintings of Victor Ekpuk}

Victor Ekpuk ${ }^{1}$ takes inspiration from a writing language of his native Ibibio in Nigeria to communicate both local and universal themes. Over the years, he has also generated other forms he uses in his drawings and paintings through several years of studio practice and research. Victor maintains that he understands only some of this sacred language called $N$ sibidi ${ }^{2}$, this is because of the secretive nature of this writing script which is said to belong only to the initiates of the male secret society among his people.

Within Ekpuk's narratives are however some recognizable symbols that are woven into the subtext of the narrative. Incidentally, some of the icons are also found in the works of other artists who come from a different ethnic society as Ekpuk. Their works show similarities in the icons used from the different societies as well as the universality of such icons or images. For example in manuscript series on figure 10, Ekpuk paints a white linear imagery of the concentric snake icon surrounded by short white lines on a pitch black background. This same icon (fig. 11) had been used by Salami Alabebe on the mural at the entrance of the Oyo palace several decades ago.

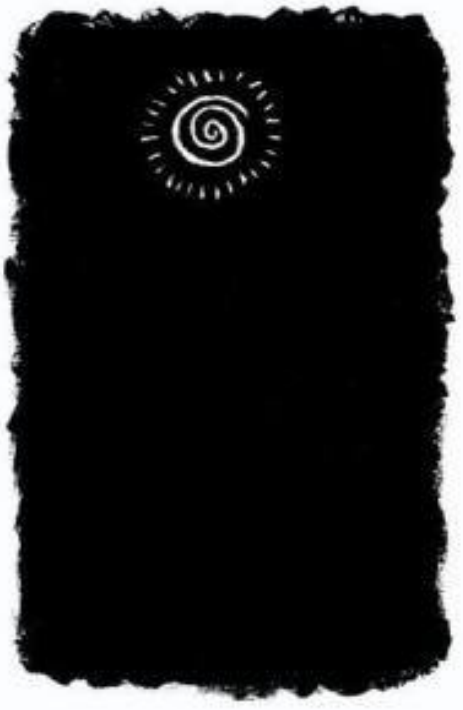

Figure 10.Victor Ekpuk Manuscript Series, Acrylic on Canvas. Photograph by Victor Ekpuk, 2004

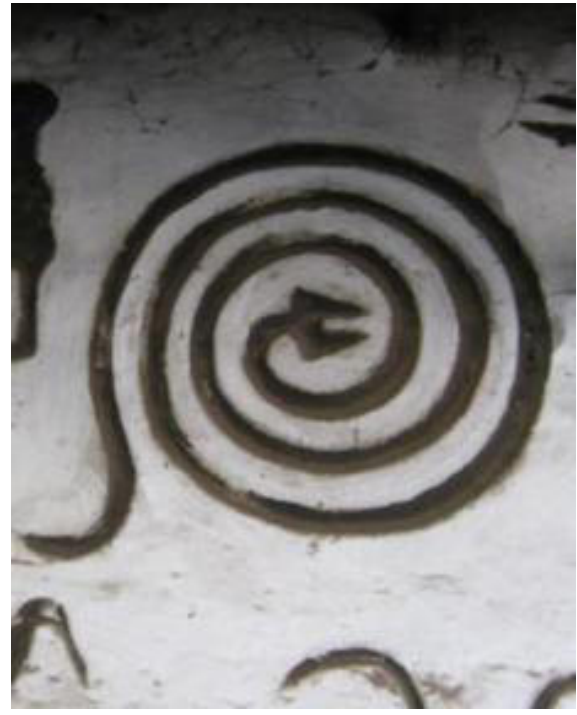

Figure 11. Snake icon from the mural by Salami Alábèbè at the Oyo palace, 1933. Photograph by Stephen Folárànmí, 2010

In Man, His Wife and Son at the Mirror, (fig. 12) Ekpuk shows how creatively diverse and accommodating and diverse a visual artist can be. With the fusion of the nsibidi script on the Islamic boards collected from Northern Nigeria, he has created contemporary sacred objects. What is more interesting here is the use of a similar icon by Mufu Onifade in two of his painting discussed earlier. Victor's work has therefore given us a clearer understanding of the icon. While the icon used on the divination tray means love, unity and compatibility, Ekpuk's painting is expressed in the title. This shows the diverse and complex nature of the nsibidi writing as well as its richness in communicating.

${ }^{1}$ http://www.seedsandfruit.com/2009/09/victor-ekpuk-artist/, accessed, July 15, 2012.

${ }^{2}$ Nsibidi is the ideographs of the Ejagham people of south-western Cameroun and south-eastern Nigeria, a unique form of writing in signs signifying ideas on several level of discourses, embodying many powers, including the essence of all that is valiant, just and ordered., see Thompson R.F, 1984, pp.227-245. 


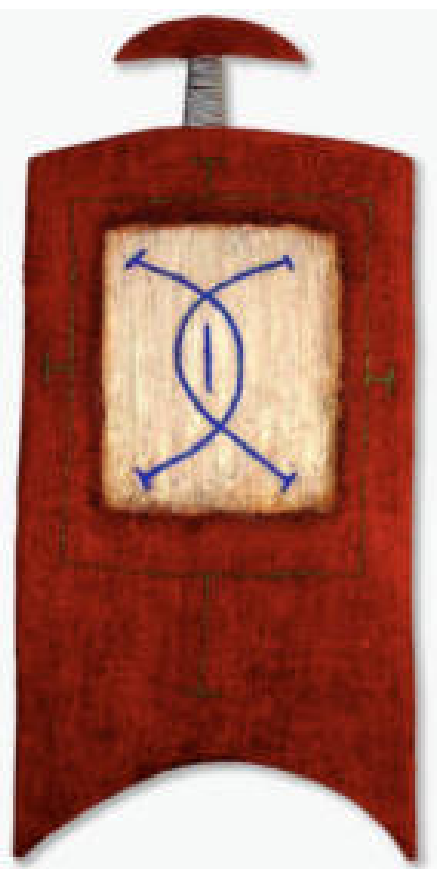

Figure 12. Victor Ekpuk, A Man, His Wife and Son at the Mirror. Acrylic on Board. Photograph by Victor Ekpuk, 2004

The combination of nsibidi signs as narratives in Victor Ekpuks works often result in new symbols or codes in script-like drawings, and these he says ${ }^{1}$ are used to express contemporary experiences. This can be better experienced if we look at Amsterdam Central, (figure 13) one of the projects created by Ekpuk during a three year stay in the Netherlands. In this mural, formulated scripts in the background accentuates the bold red central image of a figure on a bicycle as well as balances the composition with the existing fire water hose on the wall. Victor also adapted the nsibidi wheel icon which is related to the bicycle wheel meaning 'word, speech, meeting, and congress'.

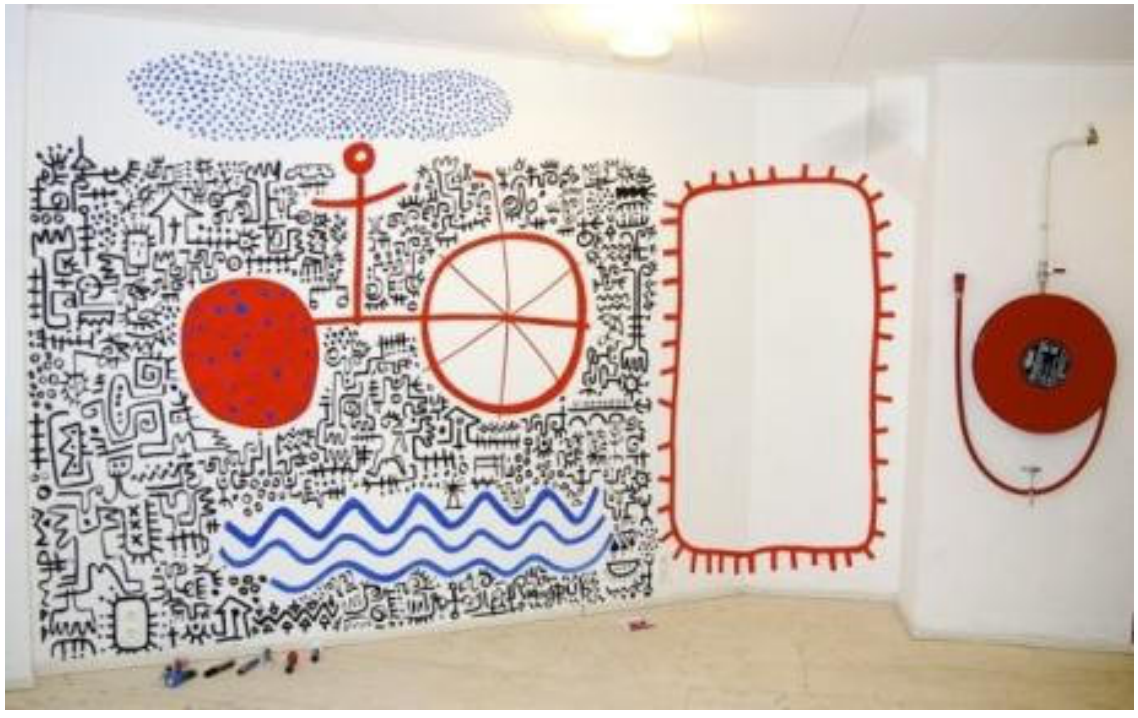

Figure 13. Victor Ekpuk, Amsterdam Central, 2008, Mural Drawing. Photograph by Victor Ekpuk, 2008

\footnotetext{
${ }^{1}$ Personal communication with Victor Ekpuk, Virginia, March, 2014
} 


\subsection{Conclusion}

These images, icons or symbols have continued to find relevance in the works of contemporary Nigerian artists and beyond is a testimony to their resilience and function as a language that can still be exploited to communicate. These icons have shown that they can continue to move both locally and transnationally as they engage different spaces. They are dynamic, and therefore ongoing. Different artists have also added to this ongoing vocabulary especially as they contact new spaces; gather experiences and engage different viewers. Conversation with some of the artists who understand the icons and images show that they continue to find the icons and images relevant and hence their constant usage because of being time-tested and time-honored visual metaphors that the Africans use in communicating coded and clear messages. In that respect, they are like oriki, cognomen in visual forms - they are condensed, articulate and succinct, and are rendered in concrete manner in praising the accomplishment of the individual or groups of people.

The study concluded that these artists under study have constantly shown their roots; an expression of "the self' which makes a work open, and legible to all, because it contains a slice, no matter how tiny of ourselves (Njami et al., (2005). Creative activities by the artists have brought to the fore man's quest for development of a better society, where order and beauty is desired by looking back at what used to be to forge a unified future base on acquired knowledge of the past merged with present day realities.

\section{References}

Abiodun, Rowland. 1989. "The Kingdom of Owo.” In Yòrubá : Nine Centuries of African Art and Thought., 91115. New York, NY: Center for African Art.

Adémúlèyá, B.A. 2007. "An Analysis of Kunle Filani’s Art over Three Decades and His Contributions to Contemporary Nigerian Art.” In Divine, Absolutely Divine-Kunle Filani in Retrospect. Lagos: Culture and Creative Art Foundation (CCAF).

Ajiboye, Olusegun Jide, Stephen Adéyemí Fọlárànmí, and Nanashaitu Umoru-Oke. 2018. “Orí (Head) as an Expression of Yorùbá Aesthetic Philosophy.” Mediterranean Journal of Social Sciences 9 (4): 59-70. doi:Doi: 10.2478/mjss-2018-0115.

Campbell, Bolaji. 2008. Painting for the Gods: Art and Aesthetics of Yòrubá Religious Murals. Trenton NJ: Africa World Press.

D’Alleva, Anne. 2014. Methods \& Theories of Art History. London: Laurence King.

Drewal, Henry John., Rowland. Abiodun, Allen. Wardwell, John Pemberton, and Center for African Art (N.Y.). 1991. Yòrubá : Nine Centuries of African Art and Thought. New York: Center for African Art.

Folaranmi, Stephen. 2012. Mural Art in Oyo Palace. Saarbrucken, Germany: LAP LAMBERT Academic Publishing.

Folárànmí, Stephen. 2002. “Creative Adaptation of Yorùbá Art Forms in Adémólá Ogunajo’s Paintings.” In Perspectives of Culture and Creativity in Nigerian Art, edited by Kunle Filani, Ademola Azeez, and Austine Amifoniye, 45-56. Lagos: Culture and Creative Art Forum (CCAF).

Folarin, Agboola. 2001. The Importance of Creative Experimentation. Inaugural. Ile-Ife, Nigeria.: Obáfémi Awólówò University Press.

Hackett, Rosalind I.J. 1999. Art and Religion in Africa. London and New York: Casell.

Harris, Michael D, and Moyosore B Okediji. 1999. Transatlantic Dialogue: Contemporary Art in and out of Africa. Chapel Hill, N.C.: Ackland Art Museum, University of North Carolina at Chapel Hill.

Idowu, E Bolaji. 1962. Olodumare : God in Yòrubá Belief. [London]: Longmans.

Kawaguchi, Yukiya. 2011. "A Fateful Journey: A Curator's Perspective." Nka: Journal of Contemporary African Art., no. 28: 106-12.

Mount, Marshall Ward. 1989. African Art; the Years Since Since 1920. First. New York, NY: Da capo Press.

Njami, Simon, Lucy. Duran, Hayward Gallery., Germany) Museum Kunst Palast (Dusseldorf, Centre Georges Pompidou., and Mori Bijutsukan. 2005. Africa remix : contemporary art of a continent. Ostfildern-Ruit; New York: Hatje Cantz; [Distributed by] D.A.P.

Ogunajo, Ademola. 2001. A Primal Treasure " in Primal Treasure. Lagos: Ademola Ogunajo.

Okediji, M. 2003. "The Shattered Gourds: The Yorùbá Forms in Twentieth-Century American Art." Washington University of Washington Press.

Okediji, Moyosore B. 2002. "African Renaissance: New Forms, Old Images in Yorùbá Art." Boulder: University Press of Colorado. http://catalog.hathitrust.org/api/volumes/oclc/49260168.html.

Panofsky, Erwin. 1970. Renaissance and Renascences in Western Art. London: Paladin.

Parrinder, G. 1967. African Mythology. The Hamlyn Publishing Group. Ltd.

Thompson, Robert Faris. 1984. Flash of the Spirit: African and Afro-American Art and Philosophy. New York: Vintage Books, Random House. 